\title{
Azolylborates for Electrochemical Double Layer Capacitor Electrolytes
}

\author{
By Robert Francke ${ }^{1}$, Dario Cericola ${ }^{2}, \#$, Rüdiger Kötz ${ }^{2}$, and Siegfried R. Waldvogel ${ }^{1, *}$ \\ ${ }^{1}$ Institute for Organic Chemistry, Mainz University, Duesbergweg 10-14, 55128 Mainz, Germany \\ ${ }^{2}$ Electrochemistry Laboratory, Paul-Scherrer-Institute, CH-5232 Villigen PSI, Switzerland
}

(Received August 17, 2011; accepted October 17, 2011)

\section{Azolylborate / Alkylammonium Salt / Electrochemical Double Layer Capacitor / Supporting Electrolyte / Cyclic Voltammetry}

Asymmetric tetraalkylammonium salts of azolylborates were synthesized and studied with respect to their suitability as supporting electrolytes in electrochemical double layer capacitors. In contrast to current conducting salts used in this device, azolylborates exhibit an excellent stability towards thermal load and moisture. In addition to good conductivity and stability towards cathodic reduction we found certain limitations when more positive potentials were applied.

\section{Introduction}

Over the past decades research on electrochemical double layer capacitors (EDLCs) as energy storage devices has attracted increasing attention since high power output for intermittent demand and functional reliability are combined. Due to the ratio between specific power and specific energy the EDLC is an ideal complement to conventional capacitors and batteries [1]. The energy is stored in the electric field of the electrochemical double layer. Additional energy may be stored by partial electrochemical charge transfer at the electrode/electrolyte interface resulting in so-called pseudocapacitance $[2,3]$. These devices can be charged and discharged at considerably higher rates than batteries with an almost unlimited number of cycles. Compared to conventional capacitors, EDLCs have a much higher specific capacitance and energy, mostly depending on the electrode surface and pore structure [4,5]. Due to its high surface area, good electronic conductivity, and electrochemical inertness, activated carbon is the most frequently used electrode material for this application [6]. Commonly, the electrolyte is composed of an aprotic organic solvent and a tetraalkyl ammonium salt of a non-coordinating anion as supporting electrolyte, in most cases acetonitrile or propylene carbonate with tetraethylammonium tetrafluoroborate (TEABF) [3,7]. The electrochemical windows of these electrolytes allow operations at significantly higher

\footnotetext{
* Corresponding author. E-mail: waldvogel@uni-mainz.de

\# Present address: TIMCAL Ltd., 6743 Bodio TI, Switzerland
} 


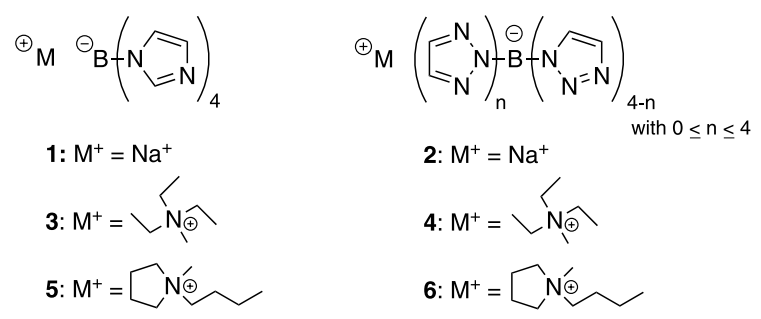

Scheme 1. Structures of the borate salts envisioned for application in EDLC test cells.

voltages compared to aqueous electrolytes. As the storable energy increases with the square of the voltage attainable on charge, these systems can typically provide a larger specific energy compared to EDLCs based on aqueous electrolytes [2].

The limited thermal and chemical stability of tetrafluoroborates combined with the liberation of highly toxic hydrogen fluoride upon decomposition incidents create a demand for alternative and non-fluorinated materials. Recently, borate salts like lithium bisoxalatoborate were identified as very potent supporting electrolytes for EDLCs [8]. We found that despite some lack of stability in the anodic region bis $\left(2,2^{\prime}-\right.$ biphenoxy)borates can be used for EDLC cells [9]. Their performance can be significantly improved by introduction of fluorine to the biphenoxy ligands [10]. In context of secondary Li-ion battery applications a survey of the known borates is given [11].

In this work we present various borate salts with five membered $N$-heterocyclic ligands as a new approach towards the creation of chemically and thermally stable supporting electrolytes (see Scheme 1). It is well-known that imidazolium and triazolium salts exhibit a pronounced stability. The explosive character can only be exploited when oxidizing counterions or azido groups are involved [12].

Since the first generation of tetrakis(1-pyrazolyl)borates in 1967, numerous derivatives with aromatic $N$-heterocycles have been reported such as tetrakis(1pyrrolyl)borates, tetrakis(1-indolyl)borates and tetrakis(1-imidazolyl)borates (1) [1316]. Generally, these compounds can be synthesized in a single step by conversion of borohydrides with the corresponding azole at elevated temperature under hydrogen evolution.

Boron azole chemistry became a field with a remarkably broad scope yielding novel classes of heterocyclic substituted borates, chelating ligands and transition metal compounds. Some of them have found application as coordinating anions for metal-organic frameworks [15-18]. Recently, tetrakis(1-imidazolyl)borates were reported as suitable components for conjugated polyelectrolyte thin films as electron transport/injection layers for organic optoelectronic devices [19]. However, no electrochemical studies based on these salts are available.

\section{Experimental}

Conductivity measurements were performed with a 856 Conductivity Module (Metrohm AG, Herisau, Switzerland) and a measuring cell consisting of two platinized 
Pt electrodes (cell constant approximately $0.82 \mathrm{~cm}^{-1}$ ). The system was calibrated prior to each measurement using an aqueous $0.1 \mathrm{M} \mathrm{KCl}$ solution.

Cyclic voltammetry was performed in a three electrode arrangement. The electrode material was $90 \% \mathrm{w} / \mathrm{w}$ activated carbon as active material (YP17 from Kuraray Chemical, Japan - BET surface area $1600 \mathrm{~m}^{2} / \mathrm{g}$ ) bound with $10 \% \mathrm{w} / \mathrm{w}$ poly(tetrafluroethene). The working electrodes (diameter: $12 \mathrm{~mm}$; thickness: $200 \pm$ $20 \mu \mathrm{m}$; average active loading: $10 \mathrm{mg} / \mathrm{cm}^{2}$ ) were punched out from self-supporting electrode material sheets. The counter electrode (YP17, diameter: $12 \mathrm{~mm}$ ) was largely oversized in charge capacity with respect to the working electrode in order to limit its potential excursion. Activated carbon (AC) was used as quasi-reference electrode $\left(E_{\mathrm{AC}} \sim 3 \mathrm{~V} v s . \mathrm{Li} / \mathrm{Li}^{+}\right)$[20]. The working and the counter electrode were separated by an unbound glass fiber separator (diameter $13 \mathrm{~mm}$ ). The working electrode/separator/counter electrode sandwich was then compressed between two titanium current collectors in the electrochemical cell by a spring (with a pressure of $\sim 50 \mathrm{~N} / \mathrm{cm}^{2}$ ). The reference electrode was placed on the side of the electrode stack. The electrochemical cells were assembled in air and then dried at $120^{\circ} \mathrm{C}$ and $20 \mathrm{mbar}$ for at least $12 \mathrm{~h}$. The dried cells were then transferred, filled with the proper electrolyte, and hermetically sealed in an argon filled glove box $\left(\mathrm{H}_{2} \mathrm{O}\right.$ and $\left.\mathrm{O}_{2}<1 \mathrm{ppm}\right)$. For the electrochemical experiments an electrochemical workstation Zahner im6ex (Zahner Elektrik, Germany) was used. The reported specific capacitance values refer only to the mass of active material in the working electrode.

Sodium tetrakis(1-imidazolyl) borate (1) was prepared according to [14] with slight modifications. In a Schlenk flask equipped with an air condenser sodium borohydride $(3.64 \mathrm{~g}, 96 \mathrm{mmol})$ and imidazole $(32.75 \mathrm{~g}, 481 \mathrm{mmol})$ were heated to $100{ }^{\circ} \mathrm{C}$ while stirring. When hydrogen evolution ceased the temperature was raised gradually to $260{ }^{\circ} \mathrm{C}$ adjusting the heating rate to the intensity of hydrogen evolution. The temperature was kept until gas evolution ceased ( $4 \mathrm{~h}$ ). The mixture was chilled to $60{ }^{\circ} \mathrm{C}$ and $100 \mathrm{~mL}$ of acetone were added while vigorous stirring. After $15 \mathrm{~h}$ the colorless precipitate was filtered off and washed three times with acetone $(20 \mathrm{~mL})$. After recrystallization from boiling ethanol and drying for $8 \mathrm{~h}\left(180^{\circ} \mathrm{C}, 5 \times 10^{-3} \mathrm{mbar}\right)$ the product was afforded as a colorless solid $\left(26.01 \mathrm{~g}, 86 \mathrm{mmol}, 90 \%\right.$, decomposition at $\left.360{ }^{\circ} \mathrm{C}\right) .{ }^{11} \mathrm{~B}$ NMR $\left(128 \mathrm{MHz}, \mathrm{D}_{2} \mathrm{O}\right): \delta(\mathrm{ppm})=0.02(\mathrm{~s}) ;{ }^{1} \mathrm{H}$ NMR $\left(300 \mathrm{MHz}, \mathrm{D}_{2} \mathrm{O}\right): \delta(\mathrm{ppm})=7.28$ $(\mathrm{s}, 4 \mathrm{H}), 7.00(\mathrm{~s}, 4 \mathrm{H}), 6.82(\mathrm{~s}, 4 \mathrm{H}) ;{ }^{13} \mathrm{C} \mathrm{NMR}\left(300 \mathrm{MHz}, \mathrm{D}_{2} \mathrm{O}\right): \delta(\mathrm{ppm})=142.9,130.6$, 124.2; HRMS calcd. for $\left[\mathrm{C}_{12} \mathrm{H}_{12} \mathrm{BN}_{8}\right]^{-}: 279.1282$; found: 279.1275 .

Sodium tetrakis(1,2,3-triazolyl) borate (isomeric mixture) (2) was prepared in a similar manner as described above for $1.1,2,3$-Triazole $(1.36 \mathrm{~g}, 36 \mathrm{mmol})$ and sodium borohydride $(20 \mathrm{~g}, 290 \mathrm{mmol})$ were gradually heated to $220^{\circ} \mathrm{C}$ under inert conditions and the temperature was kept for three days. After cooling to room temperature the solid was mechanically crushed, suspended in $100 \mathrm{~mL}$ of tert-butyl methyl ether and stirred overnight. The colorless solid was filtered off, washed three times with tertbutyl methyl ether and recrystallized from boiling acetonitrile. After drying for $10 \mathrm{~h}$ $\left(180{ }^{\circ} \mathrm{C}, 5 \times 10^{-3} \mathrm{mbar}\right)$ the product was obtained as a colorless solid $(6.29 \mathrm{~g}, 21 \mathrm{mmol}$, $57 \%) .{ }^{11} \mathrm{~B}$ NMR $\left(128 \mathrm{MHz}, \mathrm{DMSO}-d_{6}\right): \delta(\mathrm{ppm})=1.88(\mathrm{~s}), 1.73(\mathrm{~s}), 1.51(\mathrm{~s}) ;{ }^{1} \mathrm{H} \mathrm{NMR}$ $\left(300 \mathrm{MHz}, \mathrm{DMSO}-d_{6}\right): \delta(\mathrm{ppm})=7.88(\mathrm{~s}), 7.78(\mathrm{~s}), 7.70(\mathrm{~s}), 7.67(\mathrm{~s}), 7.64(\mathrm{~s}), 7.60(\mathrm{~s})$, $7.57(\mathrm{~s}) ;{ }^{13} \mathrm{C}$ NMR $\left(300 \mathrm{MHz}, \mathrm{DMSO}-d_{6}\right): \delta(\mathrm{ppm})=134.7,134.1,132.1,131.6,131.1$, 128.5, 128.2, 128.0; HRMS calcd. for $\left[\mathrm{C}_{8} \mathrm{H}_{8} \mathrm{BN}_{12}\right]^{-}: 283.1084$; found: 283.1083. 
Alkyl ammonium tetrakis azolyl borates (3-6) were prepared via salt metathesis from 1 and $\mathbf{2}$ with the corresponding alkylammonium chlorides. Due to the hygroscopic nature of the ammonium chlorides, operations were performed in Schlenk vessels under argon atmosphere. The sodium tetrakisazolyl borate $(5 \mathrm{mmol})$ and the equimolar amount of triethyl methyl ammonium chloride and $N$-butyl- $N$-methyl pyrrolidinium chloride, respectively, were heated to reflux for $5 \mathrm{~h}$ in $30 \mathrm{~mL}$ of acetone. After bringing to room temperature the mixture was filtered and the solvent removed under reduced pressure. The resulting oil was dissolved in ca. $40 \mathrm{~mL}$ of dichloromethane, washed with $10 \mathrm{~mL}$ of water and fractionated. The organic solvent was removed and the product dried for $10 \mathrm{~h}$ at $120{ }^{\circ} \mathrm{C}\left(5 \times 10^{-3} \mathrm{mbar}\right)$. The hygroscopic products were stored in Schlenk vessels under argon.

Triethylmethylammonium tetrakis(1-imidazolyl) borate (3) was obtained as a colorless solid (m.p. $\left.166-167{ }^{\circ} \mathrm{C}\right) .{ }^{11} \mathrm{~B}$ NMR $\left(128 \mathrm{MHz}, \mathrm{D}_{2} \mathrm{O}\right): \delta(\mathrm{ppm})=0.00(\mathrm{~s})$; ${ }^{1} \mathrm{H}$ NMR $\left(300 \mathrm{MHz}, \mathrm{DMSO}-d_{6}\right) \delta=7.04$ (s, 4H), 6.93 (s, 4H), 6.76 (s, 4H), 3.24 (q, $J=7.3 \mathrm{~Hz}, 6 \mathrm{H}), 2.87(\mathrm{~s}, 3 \mathrm{H}), 1.26-1.09(\mathrm{t}, J=7.3 \mathrm{~Hz}, 9 \mathrm{H}) ;{ }^{13} \mathrm{C}$ NMR $(300 \mathrm{MHz}$, DMSO- $\left.d_{6}\right): \delta(\mathrm{ppm})=139.4,128.9,121.2,55.0,46.0,7.4$.

Triethylmethylammonium tetrakis(1,2,3-triazolyl) borate (isomeric mixture) (4) was obtained as a colorless and highly viscous oil. ${ }^{11} \mathrm{~B}$ NMR (128 MHz, DMSO- $\left.d_{6}\right)$ : $\delta(\mathrm{ppm})=1.89(\mathrm{~s}), 1.73(\mathrm{~s}), 1.51(\mathrm{~s}) ;{ }^{1} \mathrm{H}$ NMR $\left(300 \mathrm{MHz}, \mathrm{DMSO}-d_{6}\right): \delta(\mathrm{ppm})=7.88$ (s), 7.78 (s), 7.69 (s), 7.66 (s), 7.64 (s), 7.60 (s), 7.57 (s), 3.19 (q, J = $7.3 \mathrm{~Hz}$, $6 \mathrm{H}), 2.82(\mathrm{~s}, 3 \mathrm{H}), 1.21-1.07(\mathrm{t}, J=7.3 \mathrm{~Hz}, 9 \mathrm{H}) ;{ }^{13} \mathrm{C}$ NMR $\left(300 \mathrm{MHz}, \mathrm{DMSO}-d_{6}\right)$ : $\delta(\mathrm{ppm})=134.7,134.1,132.1,131.6,131.1,128.5,128.2,128.1,54.9,46.0,7.4$.

$\boldsymbol{N}$-Butyl- $\boldsymbol{N}$-methylpyrrolidinium tetrakis(1-imidazolyl) borate (5) was obtained as a colorless solid (m.p. $\left.115-116^{\circ} \mathrm{C}\right) .{ }^{11} \mathrm{~B}$ NMR $\left(128 \mathrm{MHz}, \mathrm{DMSO}-d_{6}\right): \delta(\mathrm{ppm})=$ $0.02(\mathrm{~s}) ;{ }^{1} \mathrm{H}$ NMR $\left(300 \mathrm{MHz}, \mathrm{DMSO}-d_{6}\right) \delta=7.05(\mathrm{~s}, 4 \mathrm{H}), 6.93(\mathrm{~s}, 4 \mathrm{H}), 6.77(\mathrm{~s}, 4 \mathrm{H})$, $3.45-3.28(\mathrm{~m}, 2 \mathrm{H}), 3.28-3.21(\mathrm{~m}, 2 \mathrm{H}), 2.90(\mathrm{~s}, 3 \mathrm{H}), 2.09-1.96(\mathrm{~m}, 2 \mathrm{H}), 1.68-1.58(\mathrm{~m}$, 2H), $1.34-1.20(\mathrm{~m}, 2 \mathrm{H}), 0.90(\mathrm{t}, J=7.4 \mathrm{~Hz}, 3 \mathrm{H}) ;{ }^{13} \mathrm{C}$ NMR $\left(300 \mathrm{MHz}, \mathrm{DMSO}-d_{6}\right)$ : $\delta(\mathrm{ppm})=139.3,128.8,121.2,63.4,63.2,47.4,24.9,21.0,19.3,13.5$.

$N$-Butyl- $N$-methylpyrrolidinium tetrakis $(1,2,3$-triazolyl) borate (isomeric mixture) (6) was obtained as a colorless and highly viscous oil. ${ }^{11} \mathrm{~B}$ NMR $(128 \mathrm{MHz}$, DMSO- $\left.d_{6}\right): \delta(\mathrm{ppm})=1.88(\mathrm{~s}), 1.73(\mathrm{~s}), 1.51(\mathrm{~s}) ;{ }^{1} \mathrm{H}$ NMR $\left(300 \mathrm{MHz}\right.$, DMSO- $\left.d_{6}\right):$ $\delta=7.88(\mathrm{~s}), 7.77(\mathrm{~s}), 7.69(\mathrm{~s}), 7.66(\mathrm{~s}), 7.62(\mathrm{~s}), 7.57(\mathrm{~s}), 3.45-3.30(\mathrm{~m}, 2 \mathrm{H}), 3.27-3.20$ $(\mathrm{m}, 2 \mathrm{H}), 2.91(\mathrm{~s}, 3 \mathrm{H}), 2.08-1.96(\mathrm{~m}, 2 \mathrm{H}), 1.69-1.58(\mathrm{~m}, 2 \mathrm{H}), 1.34-1.21(\mathrm{~m}, 2 \mathrm{H})$, $0.91(\mathrm{t}, J=7.4,3 \mathrm{H}) ;{ }^{13} \mathrm{C}$ NMR $\left(300 \mathrm{MHz}, \mathrm{DMSO}-d_{6}\right): \delta(\mathrm{ppm})=134.7,134.1,132.1$, 131.6, 131.1, 128.5, 128.2, 128.0, 63.4, 63.2, 47.5, 24.9, 21.1, 19.3, 13.5.

\section{Results and discussion}

Remarkably, the sodium salt of $\mathbf{1}$ is stable in aqueous solutions and robust towards thermal decomposition up to $360^{\circ} \mathrm{C}$. Additionally, it is easy to synthesize with inexpensive and readily available starting materials. This prompted us to select $\mathbf{1}$ as a potential candidate for application in EDLCs. Furthermore we present $\mathbf{2}$ as a novel compound with similar chemical and thermal stability compared to $\mathbf{1}$. As $1 H$-1,2,3-triazole can coordinate via $\mathrm{N}-1$ and $\mathrm{N}-2$, an isomeric mixture is obtained upon reaction with sodium borohydride. Although five isomers are conceivable, only three could be unambigu- 

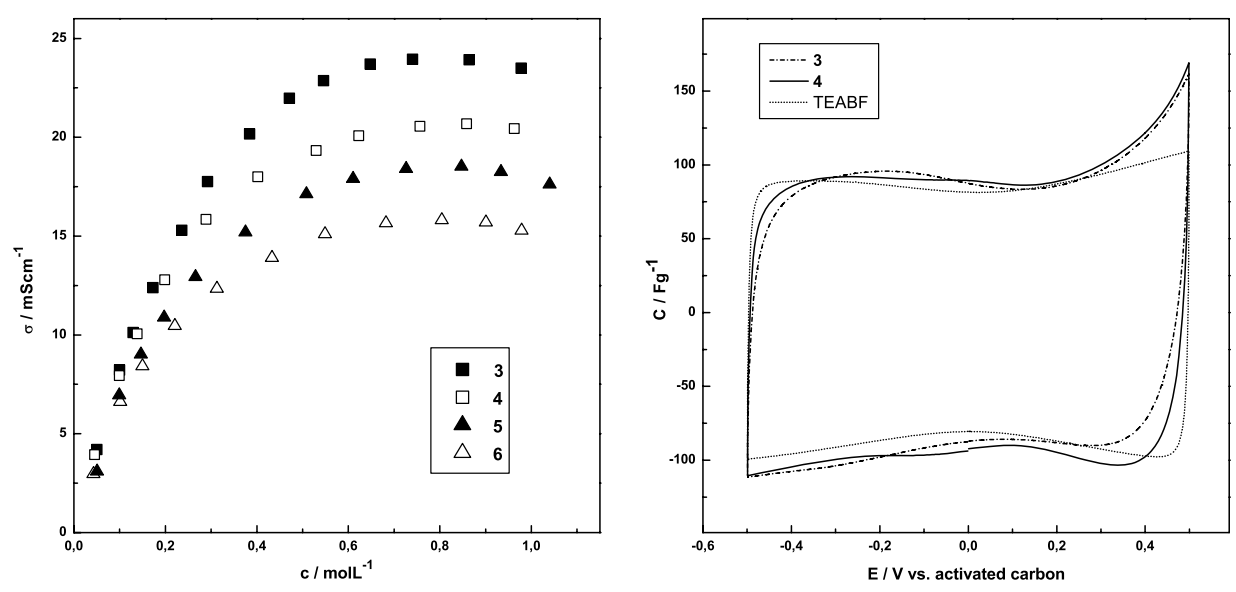

Fig. 1. Left: Plot of conductivity $v s$. concentration of 3-6; right: cyclic voltammograms of $1 \mathrm{M} 3$ (dashdotted line), $1 \mathrm{M} 4$ (solid line) and $1 \mathrm{M}$ TEABF (dotted line) in acetonitrile; unsymmetric three electrode cell arrangement, working, counter and reference electrode: activated carbon, solvent: acetonitrile, scan rate: $1 \mathrm{mV} / \mathrm{s}$, third cycles are shown.

Table 1. Conductivity of $1 \mathrm{M}$ solutions in acetonitrile of triethyl methyl ammonium tetrakis(1-imidazolyl)borate (3), triethyl methyl ammonium tetrakis(1,2,3-triazolyl)borate (4), $N$-butyl $N$-methyl pyrrolidinium tetrakis(1-imidazolyl)borate (5) and $N$-butyl $N$-methyl pyrrolidinium tetrakis(1,2,3-triazolyl)borate (6); $T=25^{\circ} \mathrm{C}$.

\begin{tabular}{cccccc}
\hline & $\mathbf{3}$ & $\mathbf{4}$ & $\mathbf{5}$ & $\mathbf{6}$ & TEABF \\
\hline$\sigma / \mathrm{mS} \mathrm{cm}^{-1}$ & $24.5 \pm 0.1$ & $20.3 \pm 0.1$ & $18.9 \pm 0.1$ & $15.2 \pm 0.1$ & $56^{1}$ \\
\hline
\end{tabular}

${ }^{1}$ Ref. [22]

ously identified via ${ }^{11} \mathrm{~B}$ NMR. The chemical shifts of the different isomers are very similar and the corresponding signals overlapping. A superimposition of signals and therefore, the presence of more isomers cannot be excluded. A separation of the isomers could not be achieved due to their similar chemical properties. But as the conductivity and the redox potentials of the individual species should not differ significantly from each other, it is convenient to study the salt as an isomeric mixture. Interestingly, the asymmetric ammonium salts $\mathbf{4}$ and $\mathbf{6}$ are obtained as oils. Although the viscosity is relatively high at room temperature, these compounds can be considered as ionic liquids. Therefore, numerous applications in other respects may be considered.

As the concentration for applications in EDLCs typically needs to be above $0.2 \mathrm{M}$ [21], unsymmetrical tetraalkylammonium salts were synthesized to provide an adequate solubility. Tetraethylammonium salts were prepared as well but were not studied due to their low solubility in acetonitrile (max. $0.2-0.3 \mathrm{M}$ ).

To evaluate the performance of imidazolyl- and triazolylborates as potential supporting electrolytes for EDLCs, conductivity measurements and cyclic voltammetry were performed (see Figs. 1 and 2). The ionic conductivity of an electrolyte mostly 
Table 2. Specific capacitances $C$ at vertex potentials, positive and negative potential limits $E_{\lim } v s$. activated carbon of the azolylborate salts $\mathbf{3}$ and $\mathbf{4}$; electrode material: activated carbon (YP17).

\begin{tabular}{lccc}
\hline & $\mathbf{3}$ & $\mathbf{4}$ & TEABF \\
\hline$C(-0.5 \mathrm{~V}) / \mathrm{Fg} \mathrm{g}^{-1}$ & $110 \pm 3$ & $110 \pm 3$ & $99 \pm 3$ \\
$C(+0.5 \mathrm{~V}) / \mathrm{F} \mathrm{g}^{-1}$ & $170^{1} \pm 5$ & $170^{1} \pm 5$ & $108 \pm 3$ \\
$E_{\lim }($ pos. $) / \mathrm{V}$ & 0.3 & 0.3 & 1.2 \\
$E_{\lim (\text { neg. }) / \mathrm{V}}$ & $-2.0^{2}$ & $-2.0^{2}$ & $-2.0^{2}$ \\
\hline${ }^{1}$ Faradayic processes involved & & \\
${ }^{2}$ Limitation by the electrochemical degradation of the binder [23].
\end{tabular}

depends on the concentration of the salt, the ion pair dissociation, the viscosity and the ion sizes. The azolyl borate anion exhibits a considerable formula weight, but on the other hand the ion pair dissociation is expected to be high due to the difference between anion and cation sizes. The measured conductivity values are comparable to symmetric alkyl ammonium tetrafluoroborates in acetonitrile (1 M solutions: $10-56 \mathrm{mS} \mathrm{cm}^{-1}$ depending on the length of the alkyl chains) [22]. The conductivity of $1 \mathrm{M}$ solutions of the azolylborate salts in acetonitrile is summarized in Table 2 and compared to $1 \mathrm{M}$ TEABF. The effect of the size of the azolylborate anion seems to lower the ion mobility and therefore, decreases the conductivity in comparison to TEABF significantly. An optimization might be achieved by a screening of different suitable cations which is, however, not subject of this study.

Concentration dependent measurements reveal a maximum of the conductivity located for all the tested electrolytes between 0.7 and $0.8 \mathrm{M}$ (see Fig. 1, left). At this point the effect of the increasing concentration of the supporting electrolyte is compensated by viscosity and ion pairing. The triethyl methyl ammonium salts $\mathbf{3}$ and $\mathbf{4}$ exhibit a higher conductivity compared to the $N$-methyl- $N$-butyl-pyrrolidinium salts $\mathbf{5}$ and $\mathbf{6}$ most probably due to the bigger size of the cation of the latter salts. Interestingly, despite the similar size and morphology of azolylborate anions $\mathbf{1}$ and $\mathbf{2}$, the conductivity of $\mathbf{3}$ and $\mathbf{5}$ is about $20 \%$ higher than for the corresponding salts $\mathbf{4}$ and $\mathbf{6}$. Differing electronic properties of the ligand spheres of borate ions $\mathbf{1}$ and $\mathbf{2}$ might cause differences in the sizes of their solvate shells or in the strength of the ion pair dissociation.

Cyclic voltammetry of $\mathbf{3}$ and $\mathbf{4}$ was performed in asymmetric EDLC test cells with $1 \mathrm{M}$ solutions in acetonitrile using activated carbon as electrode material (see Fig. 1, right and Fig. 2). In the range of -0.5 and $+0.5 \mathrm{~V}$ both salts show very similar behavior upon charging and discharging. Their voltammograms (see Fig. 1, right, third cycle is shown) are almost box-shaped with a slight increase of the current beginning at roughly $0.3 \mathrm{~V}$. At $-0.5 \mathrm{~V}$ the specific capacitances with respect to the active electrode mass are $110 \mathrm{Fg}^{-1}$ for both salts, which is about $10 \%$ higher than for $1 \mathrm{M}$ TEABF in acetonitrile. On the other hand the charge exchange dynamics of $\mathbf{3}$ and $\mathbf{4}$ are slower which is indicated by the slopes of the capacitance curves after reversal of the potential. The higher slope for $1 \mathrm{M}$ TEABF compared to $\mathbf{3}$ and $\mathbf{4}$ is a clear sign for faster charging and discharging of the device. The capacitances for the positive vertex potentials are for both salts $170 \mathrm{~F} \mathrm{~g}^{-1}$, which is $60 \mathrm{~F} \mathrm{~g}^{-1}$ higher than for the standard electrolyte. In contrast to the negative vertex potential this suggests that faradayic processes are involved. 


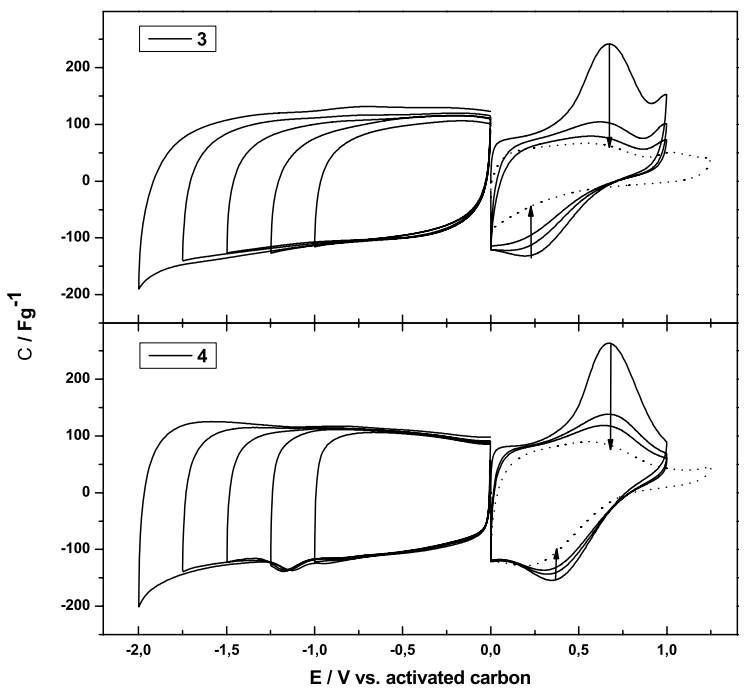

Fig. 2. Cycle opening experiments with 3 (top) and 4 (bottom), conditions: see Fig. 1, for each potential limit only third cycles are shown, except for 0 to $+1 \mathrm{~V}$ (three cycles); decreasing capacitances in the positive regime are indicated with arrows; scan rate: $1 \mathrm{mV} / \mathrm{s}$.

Stepwise increasing of the upper vertex reveals that the electrolyte slowly decomposes above $0.5 \mathrm{~V}$ (see Fig. 2). A quasi reversible redox reaction followed by a significant loss of capacitance in the following cycles is observed. The current densities diminish more drastically upon cycling between 0 and $+1.25 \mathrm{~V}$ (dotted line, Fig. 2). Oxidative formation of a film on the surface blocking the pores of the electrode material could be the reason for the lowering of the performance at higher potentials. In contrast, during cycling up to $1.6 \mathrm{~V}$ using a glassy carbon disc as working electrode this reaction could not be observed with $\mathbf{3}$ and $\mathbf{4}$. Consequently, this reaction is surface sensitive and strongly depends on the choice of the electrode material.

For $\mathbf{3}$ and $\mathbf{4}$ the potential in the negative region is limited by the onset of degradation of teflon binding material, which typically occurs at $-2 \mathrm{~V}$. This is also the case with the standard electrolyte [23]. Therefore, the resulting potential window of the electrolytes based on $\mathbf{3}$ and $\mathbf{4}$ is determined to be about $2.3 \mathrm{~V}$.

All the values estimated with cyclic voltammetry for electrolytes based on imidazolylborate $\mathbf{3}$ and triazolylborate $\mathbf{4}$ are summarized in Table 2 and compared to data for tetrafluoroborates in acetonitrile.

The most important drawback of azolylborates as supporting electrolytes is the limited anodic stability towards activated carbon (stable up to $+0.3 \mathrm{~V}$ ), which is about $0.9 \mathrm{~V}$ lower than for the standard electrolyte [23]. Due to electrostatic reasons the anion is the limiting part of the supporting electrolyte in the positive sweep. A reasonable explanation for the sensitivity of the borate anions $\mathbf{1}$ and $\mathbf{2}$ towards anodic oxidation is the Lewis basicity and nucleophilicity of the nitrogen containing heterocycles. For example, a strong tendency of the azolylborates to act as hydrogen bond acceptors is reported in literature [18]. Furthermore, imidazolylborates can undergo a fourfold 
$N$-alkylation yielding the corresponding trivalent cationic species [24]. The presence of catalytically active functional groups on the surface of activated carbon derived electrode materials (e.g. hydroxy, carbonyl, carboxylic acid and phenol moieties) narrows the potential window of the electrolyte significantly compared to inert materials [4]. Interactions between these functional groups on the electrode surface and the reactive sites of the borate anion might cause the lower anodic stability of supporting electrolytes $\mathbf{3}$ and $\mathbf{4}$ towards activated carbon compared to glassy carbon.

On the other hand, in contrast to the standard electrolyte, the studied salts exhibit an excellent long term stability towards thermal load and moisture. Their stability towards reduction is adequate for application in EDLC cells. Additionally, the tetrakisazolylborates can be synthesized in one step from cheap and readily available starting materials, followed by a simple salt metathesis.

\section{Acknowledgement}

Financial support by Bundesministerium für Bildung und Forschung (HE-Lion, 03X4612J) is highly appreciated.

\section{References}

1. a) J. R. Miller and P. Simon, Science 321 (2008) 651; b) M. Winter and R. J. Brodd, Chem. Rev. 104 (2004) 4245; c) K. Naoi and P. Simon, Interface (2008) 34.

2. B. E. Conway, Electrochemical Supercapacitors. Kluwer, New York (1999).

3. R. Kötz and M. Carlen, Electrochim. Acta 45 (2000) 2483.

4. A. G. Pandolfo and A. F. Hollenkamp, J. Power Sources 157 (2006) 11.

5. a) P. Simon and Y. Gogotsi, Nature Mat. 7 (2008) 845; b) P. Simon and A. Burke, Interface (2008) 38 .

6. I. V. Barsukov, C. S. Johnson, J.E. Doninger, and V.Z. Barsukov (Eds.) New Carbon Based Materials for Electrochemical Energy Storage Systems, NATO Science Series, II-299. Springer, Boston (2006).

7. P. Kurzweil and M. Chwistek, J. Power Sources 176 (2008) 555.

8. S. Yu, W. Li, Z. Yang, N. Zhang, N. Gu, and L. Gao, Z. Phys. Chem. 222 (2008) 1579.

9. S. R. Waldvogel, I. M. Malkowsky, U. Griesbach, H. Puetter, A. Fischer, M. Hahn, and R. Kötz, Electrochem. Commun. 11 (2009) 1237.

10. a) R. Francke, D. Cericola, R. Kötz, G. Schnakenburg, and S. R. Waldvogel, Chem. Eur. J. 17 (2011) 3082; b) R. Francke, G. Schnakenburg, and S. R. Waldvogel, Org. Lett. 12 (2010) 4288; c) R. Francke, G. Schnakenburg, and S. R. Waldvogel, Eur. J. Org. Chem. (2010) 2357.

11. a) S. S. Zhang, J. Power Sources 162 (2006) 1379; b) K. Xu, Chem. Rev. 104 (2004) 4303.

12. R. P. Singh, R. D. Verma, D. T. Meshri, and J. M. Shreeve, Angew. Chem. Int. Ed. 44 (2006) 3584 .

13. a) S. Trofimenko, J. Am. Chem. Soc. 89 (1967) 3170; b) J. Emri, B. Gyori, and P. Szarvas, Z. anorg. allg. Chemie 400 (1973) 321; c) B. Gyori, J. Emri, and P. Szarvas, Acta Chim. (Budapest) 86 (1975) 235. d) S. A. A. Zaidi, and M. A. Zaboor, Transition Met. Chem. 17 (1992) 295.

14. S. Chao and C. E. Moore, Anal. Chim. Acta 100 (1978) 457.

15. B. H. Hamilton, K. A. Kelly, W. Malasi, and C. J. Ziegler, Inorganic Chemistry 42 (2003) 3067.

16. B. H. Hamilton and C. J. Ziegler, Inorganic Chemistry 43 (2004) 4272.

17. a) J. Zhang, T. Wu, C. Zhou, S. Chen, P. Feng, and X. Bu, Angew. Chem. Int. Ed. 48 (2009) 2542; b) S. Zheng, T. Wu, J. Zhang, M. Chow, R. Nieto, P. Feng, and X. Bu, Angew. Chem. Int. Ed. 49 (2010) 5362. 
18. J. Zhang, T. Wu, P. Feng, and X. Bu, Dalton Trans. 39 (2010) 1702.

19. a) J.H. Seo and T.-Q. Nguyen, J. Am. Chem. Soc. 130 (2008) 10042; b) R. Yang, Y. Xu, X.-D. Dang, T.-Q. Nguyen, Y. Cao, and G. C. Bazan, J. Am. Chem. Soc. 130 (2008) 3282.

20. P. W. Ruch, D. Cericola, M. Hahn, R. Kötz, and A. Wokaun, J. Electroanal. Chem. 636 (2009) 128.

21. J. P. Zheng and T. R. Jow, J. Electrochem. Soc. 144 (1997) 2417.

22. M. Ue, K. Ida, and S. Mori, J. Electrochem. Soc. 141 (1994) 2989.

23. P. W. Ruch, D. Cericola, A. Foelske-Schmitz, R. Kötz, and A. Wokaun, Electrochim. Acta 55 (2010) 4412.

24. a) H. Li, Y. Xu, and G.C. Bazan, US20100145062A1 (2010); b) C. J. Ziegler, US20060124902A1 (2006). 